\title{
PROPOSAL FOR A SHARED CLASSIFICATORY TREE FOR DOBES LANGUAGE DOCUMENTATIONS AND OTHER SOCIO-CULTURAL DATA BASES. ${ }^{1}$
}

\author{
Jürg Gasché ${ }^{1}$, Frank Seifart ${ }^{2}$ \\ 1 Instituto de Investigaciones de la Amazonía Peruana - IIAP, Programa de Investigación de Sociodiversidad \\ 2 Max Planck Institute for Evolutionary Anthropology, Leipzig, Germany
}

\begin{abstract}
This article proposes a classification for socio-cultural and linguistic data bases, especially those that document society, culture and language of Amazonian indigenous or rural mestizo people. The proposal was elaborated in the context of a DOBES language documentation project about the language use of the "People of the Center" (Bora, Witoto, Ocaina, Nonuya, and Resigaro). The basic principles of this proposal are derived from Bakhtin's/Vološinov's theory of the proposition.
\end{abstract}

KEYW ORDS: Amazon, Indigenous people, data base, socio-cultural classification, Bakhtin / Vološinov.

\section{PROPUESTA PARA UN ARBOL CLASIFICATORIO COMPARTIDO DE DOCUMENTACIONES LINGÜÍSTICAS DOBES Y PARA OTRAS BASES DE DATOS SOCIO-CULTURALES}

\section{RESUMEN}

El artículo propone una clasificación para bases de datos socio-culturales y lingüísticas, particularmente las que documentan la sociedad, cultura y lengua de pueblos indígenas y población mestiza rural de la Amazonía. La propuesta fue elaborada en el contexto de un proyecto de documentación lingüística en el marco DOBES dedicado a documentar el uso de las lenguas de la "Gente del Centro" (Bora, Huitoto, Ocaina, Nonuya y Resígaro). Los principios de esta propuesta fueron derivados de la "teoría del enunciado" de Bajtin / Vološinov.

PALABRAS CLAVE: Amazonía, pueblos indígenas, base de datos, clasificación socio-cultural, Bajtin / Vološinov.

1 This paper is based on experiences from the documentation project DOBES "Documenting the Languages of the People of the Center, especially Bora and Ocaina" (Seifart, Fagua, Gasché \& Echeverri 2009), realized in the frame of an agreement between IIAP-Iquitos, the Indian federation of Ampiyacu (FECONA) and the University of Bochum-Germany, and financed by the Volkswagenstiftung. 


\section{INTRODUCTION}

The social organization of the People of the Center, a multilingual cultural complex in the North West Amazon, has been analyzed in the framework of the study of forest dweller society (Spanish: sociedad bosquesina; Portuguese: sociedade florestina) (Gasché 2007; Gasché \& Echeverri, 2004; Gasché \& Vela, 2004; Gasché et al., 2005). The categories heuristically employed in that analysis give an extensively account of the social and ecological interactions of the People of the Center. These categories underlie the classification of types of speech events, which is used in the People of the Center documentation project to organize the sessions in a hierarchical corpus tree (Seifart et al., 2009). This classification is at the same time a tool for ensuring completeness of the documentation, in the sense of inclusion of examples of each major event type identified in such a classification (Seifart, 2008). Such a classification underlies and facilitates research in a number of linguistic and cultural aspects, including, for example, comparative rhetorics (Kennedy, 1998). This programmatic paper discusses a number of basic classificatory criteria (which can probably be applied - with certain modifications - to most "tribal" societies) in order to invite a collective reflection on common criteria for setting up classifications of language (and socio-cultural) documentation data, as collected by, e.g., DOBES projects, and to facilitate transparency and comparative research.

\section{AIM S OF A GENERAL CLASSIFICATORY TREE}

The ideal aim of a linguistic and socio-cultural documentation can be defined as trying to grasp any possible use of language that may occur within a society. To approach this aim we base ourselves on Mikhaíl Bakhtin's concept of situation (see section 3, below) in order to establish a pragmatic framework for each form of discourse ${ }^{2}$, which is embedded in a concrete - materially, socially and culturally definable situation. In our approach, these are the central concepts in defining the branches and nodes of a classificatory tree of a language documentation.

But what is the evidence for such forms of discourse and situations? We know from experience that not every single situation corresponds to a proper form of discourse that can be defined by itself. It is also obviously not necessary to document any possible situation in order to set up an inventory containing all existing forms of discourse within a society (and a language). Therefore, the proposed criteria should also be useful to find out in which situations the speakers of a given community use different forms of discourse and in which they do not.

The proposal is thus to work towards the establishment of an analytical instrument for the definition of situations covering the totality of social practice in the society that is subject to investigation ${ }^{3}$. The establishment of such an instrument has four main aims:

(1) to get a global view of real-life situations in a society in order to be able to explore consciously a great variety of situations and to observe the different forms of discourse that occur in such speech communities with the final goal to discover the nature and functions of the linguistic variations and to document them following an appropriate sampling method.

(2) The second aim of this analytical instrument is, far beyond the compliance with common documentation principles, to allow us to conceive a complete socio-cultural documentation of a determined society. Thus, this instrument does not only aim at keeping records of language use, but all kinds of social and cultural practices of indigenous people in the Amazon region (and in others where societies are similar), also including communities at various stages of transculturization or communities of entirely "Western" ancestry. In accordance with this intention it is very useful to have a conceptual and analytical framework at hand which allows for a classification of all the social situations that might occur.

(3) The third aim consists of setting the stage for creating, in collaboration with other language documentation projects, a comparable classification throughout most DOBES projects. Many classifications applied by projects until now appear idiosyncratic and are often not transparent to outsiders. Common criteria for data classification would facilitate comparative research, such as research on comparative rhetorics, and on everyday and ritual behavior. More generally, it facilitates the comparison of similar situations in different societies and the varying discourse forms that are linked to them in

\footnotetext{
2 This concept is derived from the bakhtinian concept of forme de l'énoncé as it appears in Todorov 1981. A recent publication makes us suspect that this theory originally was Vološinov's (2010).

3 We have in mind here primarily so-called "tribal", fundamentally subsistence-based societies (today generally with some involvement in modern market relations), in which most of the endangered languages are spoken that are documented by DOBES projects, be they in Africa, Asia, Oceania, Australia, or America. The definition of situations (with their corresponding discourse forms) in complex and modern societies would be more complicated, requiring a new and perhaps bigger effort, but we assume, this would not be impossible.
} 
order to get a broader and deeper understanding of how speech forms in human societies are shaped for socio-cultural and pragmatic purposes. It is an essential tool to help us understand by what linguistic and rhetoric means people "act" (in the concrete sense of "do things") in society. Are they similar all around the world? Are there geographical or cultural areas of similarity?

(4) A rich and common classification also aims at a shared contextualization of linguistic means. Only when the linguistic elements (in a more narrow sense) are characterized through a comprehensive and broadly accepted classification as situation-specific and functional means, they acquire the necessary pragmatic value we have so long been unaware of, and human linguistic creativity will be better captured, illustrated, and understood.

\section{BASIC PRINCIPLES OF CLASSIFICATION}

For setting up such an analytic instrument, we follow Bakhtin's (Bajtin 1995, see also Todorov 1981) concept of situation which defines a social, material, cultural, and pragmatic, frame in which the form of discourse corresponds to the performance of a discourse activity, i.e. a speech act. The speaker "acts" by means of a certain form of discourse that is applied in a certain situation with a specific intention which has a particular cultural form and social value. The situation is evidently not a state, but a moment or sequence within a complex activity, which inevitably serves a social purpose. If we want to explore the situations that can possibly occur within a society, we have to ask ourselves: which are the possible activities of their members? It is therefore necessary to combine Bakhtin's approach with that of Leontiev (1984) who defines the mutual interrelations of activity, conscience and personality, - a theory which was later broadened and enhanced by Klaus Holzkamp (1985, 1995, 1997-2006), founder of the school of "critical psychology" and "intersubjetive science".

The following explanations show by what conceptual means we define the universe of socio-cultural situations in which the discursive activities occur or possibly occur in a tribal society, as that of the People of the Center. This socio-cultural universe - in which the situations due to the presence and activities of the Western researchers is included - is represented graphically by a classification tree that establishes a hierarchy between the categories through which we analyze and define generic and various more specific criteria. Through these criteria, every possible and observable situation in which a speech act or event in a specific form of discourse can occur and can be considered (together with the corporal gestures) as constituent of an activity, which has to be understood as socially conditioned and culturally formed.

As a consequence of this hierarchy, going from the generic to the specific, the definition of a concrete situation by means of the multi-branched classification tree (see Appendix) results from multiple links we establish between terminal nodes of this tree. To illustrate and justify this procedure, we will discuss the categories in their hierarchical order that will help us to approach and to characterize the observed and possibly occurring situations in one type of tribal society and to situate the linguistic documents (as being always part of an activity) in their real and practical socio-cultural context.

In the classification tree we first distinguish two main branches: (1) a branch called "Linguistic classification" and (2) a branch called "Socio-cultural classification". Each session documenting a specific situation is linked to the language, languages or dialects used by the people involved in the situation documented. The classification of documents according to languages (or dialects) is relatively straightforward. The socio-cultural classification which allows us to identify by means of a situation all the speech acts we are documenting within the totality of socio-cultural practices, on the other hand, is a more complex issue and will be the focus of the remainder of this paper, using the People of the Center as our main example.

The documentation of variable language functions, which are connected to different situations, requires distinguishing at a basic level between situations in which we as collectors from the "outside" participate as dialogue partners and situations in which we do not intervene beyond being present as observers. The social frame of the latter situation is characterized by an everyday occurrence of such situations within the local community. Thus we distinguish situations we create ourselves for our research and documentation purposes (2.2) from situations produced by local activities, which we can observe and document (2.1). The latter do not necessarily imply that we are not addressed by the speakers, which in turn documents the specific form of discourse that refers to situations where people from outside the community get involved in the context of a local event. "Observed situations" (2.1) and "situations created by a linguist or anthropologist" (2.2) are the next branches in our tree hierarchy, to which a third branch (2.3) is added which contains sessions documenting the habitat and the geophysical circumstances of the society, without necessarily containing discourses in the indigenous language.

Branch 2.2 "Situations created by a linguist or 
anthropologist" is easy to grasp, since it follows the logic of the person that creates this specific situation for his or her own purposes, which usually means purposes according to a scientific classification, which is split up into different fields of anthropological and linguistic research. Under this node, for example, an elicitation session is filed, but also, for example, the recitation of a narrative text when it is produced solely in response to the collector's request.

Branch 2.1 "Observed situations" and its subcategories require further explanation, particularly because the terminology used is derived from our analysis of the society of the People of the Center and Amazonian forest-dweller societies in general (Gasché 2007; Gasché \& Echeverri 2004; Gasché \& Vela 2004; Gasché, Vela, Vela \& Babilonia 2005). This analysis, which is confirmed by studies on other American native peoples, leads us to distinguish primarily two sub-classes of situations and discourse forms (Gasché to appear a): 2.1.1 "Ritual situations and discourses", which generally correspond to relatively formal discourses, and 2.1.2 "Everyday situations and discourses", which usually correspond to informal discourse. An analysis of the social perspective of these two discourse classes has revealed that these two take place within different social spheres: "Everyday situations and discourses" (see section 5, below) takes place in the common boundaries of the local community (nowadays a village, but traditionally defined by one round house in the case of the People of the Center), while "Ritual situations and discourses" takes place when the relations between various such local communities and the relations with the natural elements are focused on or implied (see section 4).

Everyday situations and discourses" takes place between people that are linked through various ties kinship, affinity, neighborhood, or just friendship. These people meet, talk, and often work together every single day. This kind of discourse may be subject to variation, for example, depending on the type of kinship or other social relations (siblings, equality, parental relation, respect towards elders, intimacy, joking etc.). Two basic parameters here are relations based upon respect towards old people, on the one hand, and relations allowing sexual allusions (e.g. between brother-in-law and sister-in-law), confidential matters and jokes etc., on the other. Each and every relationship is realized by one person addressing another, that is, through a form of discourse. Nevertheless, it is not only the daily interaction of co-residents that provides the social grounds for this kind of discourses and that distinguish them from ritual discourses, but also the contents of these discourses which cover all sorts of ordinary things and day-to-day topics that occur in the round house or the community.

Nowadays everyday discourse among the People of the Center also includes events of neighboring communities, the city, the country, and the world (e.g. comments on sport events and wars). This information is shared under the heading "news" among the members of the community. This special kind of discourse expresses a "profane" vision of the world and the relationship of the community with its environment, its region and its country, with the great majority speaking regional Spanish (Loretano). We could call it a vision of a "citizen", which has been implemented in school and in the relations with the urban society and markets. In more isolated and more traditional communities, everyday discourse is only realized among people living in the same community and deals almost exclusively with situations and elements of local life. Even though the contents are of an "ordinary" and "profane" nature, it is worthwhile to investigate the question of "Who says what to whom for what purpose?" because we observed that not everyone says everything to every other. The ties and degrees of familiarity and confidentiality (or the lack of it) is based on kinship and other social relations and have to be specified between the members - men and women, old and young people, kinship ties etc. - of a local community to understand how language "works" socially and manifests itself in situations we have to define.

\section{RITUAL DISCOURSE}

As mentioned above, "Ritual Discourse" (2.1.1) refers to social relationships that link one round house to others and to the forest environment, and it is these relationships between various round houses and with nature, which give the content of or constitute what we call indigenous society of the whole People of the Center (which comprise eight ethnolinguistic groups). This society acts and manifests itself in rituals and festivals, where members of several round houses gather in one round house. These form diverse groups (hosts, co-workers, guest dancers, supplementary guests) or appear as single actors which accomplish different ceremonial roles and functions (festival organizer and his wife, his assistant, the leader of the co-workers, the ceremonial partner, hunter-singers, singers as dance leaders). In the ritual discourses, however, the participants of other co-residential groups together with all ceremonial activities and discourses are referred to in terms of a common "historical" basis, that means, the "creation story of the world" and of the ceremonial order that is the basis for the indigenous society itself. This creation story includes natural beings, referred to by kinship terms 
which make us understand that they are also members of the indigenous society. Therefore, in our case the concept of society encompasses the human society as well as nature, seen as a whole in a constant creation process achieved with the active participation of mankind and with ritual discourses being a formal and observable expression of a sociological unitary vision which we can evoke by means of the term "socie-ture".

This holistic vision has been observed in many Amazonian, American-Indian and tribal societies in general, and is related to the low degree of labor division and technical control over natural forces. Yet, so far little attention has been paid to the social functions of formal ritual discourse and its role for the expression, control and practice of "external" relations, that is, relations linking one local coresidential group (round house or village) to others of the same kind, and to nature, without which we cannot speak about one indigenous society. In a way, ritual discourse is imbued by indigenous philosophy in the sense that the terms indigenous people use and articulate in a determined order and form evoke the origin of the world and the permanent creation process. Ritual discourse is carried out in rituals or festivals and it expresses moral values - good and bad, but not always distinguishable in accordance with our "Western" ethical values - that underlie and guide all human activities and especially ritual, that is social, activities.

We have classified this type of discourse (i.e. the ritual discourse) as "formal", too. The use of the adjective "formal" is justified by the fact that indigenous people themselves distinguish different forms of such discourses by using generic terminology for formal subgenres and are aware that in such a language they do not speak in everyday life and that it has to be learned by those who accomplish a ritual charge. Some of these ritual discourses are spoken, others are sung. These types of discourse are memorized to different degrees; some include the possibility of invention of, for example, new songs which conform to the specific pattern prescribed by a specific genre. However, there is a clear distinction to be made between strictly memorized forms of discourse which have to be repeated faultlessly, without making omissions or changing the given order of the terms (among some but not all of the groups of the People of the Center), and discourse types that adopt a conventional rhetorical form, but are improvised to a considerable degree, following a traditional conceptual framework. An example of the latter is the recitation of the creation process, from which - in accordance with specific situations within the unfolding of the ritual - the relevant passages or sequences are rhetorically performed (Gasché to appear b).
In the society of the People of the Center, the social responsibility (that means: the responsibility to make the society - and therefore the continuous creation process - lies in the hands of those who have memorized the ritual key discourses and have a command of ceremonial rhetoric. The importance of have command of the art of rhetoric in order to be the "chief" of an indigenous community (village or roundhouse) in the Amazon or Amerindian region has been mentioned by many authors (Lévi-Strauss 1944; Clastres 1974, 1980; Santos 1986; Descola 1988), but the rhetoric itself has hardly been subject to systematic research, and if this has been the case, it was the anthropologists who were interested in this phenomenon and not the linguists. The NorthAmerican school of "ethno-poetics" (e.g.: Gumperz \& Hymes [eds.] 1964. 1972; Hymes 1962, 1981; Jacobson 1960; Urban 1991; Sherzer 1990: Sherzer \& Urban [eds.] 1986; Sherzer \& Woodbury [eds.] 1987; Baumann 1984) has devoted many theoretical, methodological and descriptive works about Amerindian discourses, and its theoretical framework can suggest perhaps another tree structure, so we are open for discussion.

Within the category of ritual discourses that is linked to ritual situations in which "external" relations (i.e. between local co-residential groups) are established and managed, there are two important sub-classes, which will be discussed in the following: 2.1.1.1. "Daily situations" and 2.1.1.2. "Occasional situations".

There is a social framework with respect to formal discourse in the daily life of the People of the Center (2.1.1.1.), which takes place almost every evening when the male members of the local group gather in the round house, in a place called by the Witoto jiibib?r? "coca square". During the conversation at these meetings, they consume tobacco paste (lleera) and coca powder (jiibie), which are indispensable ingredients for ritual discourse, since they open up the mind of all men for the spiritual inspiration of the "creator" and his different manifestations ("spirits", "ancestors", "souls"). Within this daily ritual framework the members and, above all, the "chief" of the round house (illa.ma), take care of the well-being and the health of the local community. This implies the mental control by means of discourse of all social forces (neighboring groups, magicians, natural beings), which might have a negative influence on the life of the group: cause damage, accident, illness, conflict, anger, etc. At the same time the men also discuss the activities they are planning for the upcoming days. They also solicit the help of other families in their tasks. By agreements settled upon in a conversation over tobacco juice and coca powder the 
men commit themselves to the given word.

For that reason, we call these exclusively masculine meetings at night in the coca square the social frame of committed word, formulating the hypothesis that in different tribal communities one or various social situations can be identified in which the speaker is committed to subsequent actions by the words uttered. Formal ritual discourse, memorized or only performative, also has the characteristic of talking "to make things happen" (Witoto monaitallena, literally "to make them dawn"), so that its words would come true in real life.

So-called occasional ritual discourse (2.1.1.2), on the other hand, is pronounced on special ritual occasions, mainly when a festival (Witoto rafue) is prepared or carried out (2.1.1.2.1) or when a healing is carried out by a prayer $(j ?$ ? $a)(2.1 .1 .2 .2)$. The tree in the appendix shows that within the class "festivals" we distinguish under 2.1.1.2.1.1 "Festival types" (according to ethnolinguistic groups: Bora, Witoto, Nonuya, Ocaina, Resígaro, etc.) and 2.1.1.2.1.2 "Phases" (of the "festivals"). The phases are again subdivided into 2.1.1.2.1.2.1 "Preparations" (which may start up to a year before the actual celebration, comprising male and female activities, discourses and songs) and 2.1.1.2.1.2.2 "Celebrations". The celebration itself is constituted by several sequences: delivery of game, welcoming the guests, exchange, ritual interactions, farewell, conversations, discourses, songs. The songs can be classified according to the moment of their occurrence during the festival: entry songs, songs of the day, songs of the night, songs of the dawn, farewell songs, but also according their genre: drinking songs (duos), flute songs, solo songs and chorus songs (that have their own genres). Category 2.1.1.2.2 "Healings" has two sub-categories: Icaros (prayers or spells) and preventive and propitiatory ("magic") formulae.

\section{EVERYDAY SITUATIONS}

In this section, we discuss some of the subcategories within "Everyday situations" (2.1.2). This category is subdivided into "Social frame" (2.1.2.1) and "Activities" (2.1.2.2). With those two terms we can link the action of every person or group to the social units we can observe and identify. Which exactly are these concrete social units in which the activities take place? There are domestic units (or households), solidarity groups (which unite various domestic units for the realization of an activity, following ties of consanguinity, affinity, godparenthood, neighborhood, friendship), community (formal and legal frame) and institutions. The latter refers to groups which were organized in the community through influence of national society (school, sports club, church, folkloristic group, congress of the indigenous federation). A last category of social frames is the city where the members of the community go shopping, settle administrative affairs, visit their family and go to vote, etc. Within each kind of social unit, we can distinguish the place (house, garden, bath place, forest, river) or social events (communal work, work parties of different kinds, communal assembly) within which the social units are observable.

The "Activities" (2.1.2.2) are subdivided into comprehensive categories that are familiar from anthropological monographs and correspond to our pragmatic experience: recreation, recollection, extraction of wood, hunting, fishing, horticulture, construction, handicraft, cooking and domestic activities, commerce, tourism, and folklore, doing the laundry, body care and hygiene, cleaning around the house, child-caring, games of children and adolescents, and sports. As can be observed in the proposed tree in the appendix, each of these activities can be subdivided into multiple subactivites, according to the classificatory refinements desired, depending on the diversity of the socio-cultural situations we observe and whose distinction seems to be of importance. For example, there are multiple ramifications under the headings of "Horticulture" and "Commerce" in the classificatory tree in the appendix.

\section{CROSS-CLASSIFICATION}

At this point it is important to remember that the situation, which provides the frame for any form of discourse, is defined by links between various terminal nodes of several branches within the comprehensive classification. One example is given in (1):

(1) 1. Linguistic classification - Witoto - dialect buиe

2. Socio-cultural classification - Observed situations - Ritual situations - O c c a s i o $\mathrm{n}$ a 1 situations-Festival-Witoto-lluak?

3. Socio-cultural classification - Observed situations - Ritual situations - O c c a s i o n a 1 situations - Festival - Phases - Preparation Female Activities - Cahuana

4. Socio-cultural classification - Observed situations - Ritual situations - O c c a s i o $\mathrm{n}$ a 1 situations - Festival - Phases - Preparation Discourses-Memorized- Somarafue

The documented ritual discourse characterized in (1) is in the Witoto buиe dialect. It corresponds to 
a situation defined by four terminal nodes from the socio-cultural classification: buиe, lluak?, (preparation of) cahuana drink, and memorized (discourse). This form or "genre" of discourse is called somarafue and the discourse itself ja?gab? somaja "incantation of the cahuana" in Witoto, and this is the name of the corresponding session in our archive. When we have - as in this case - a version of the same discourse in another dialect of Witoto $(m . n . k a)$, the link to the first end point simply will change, but the rest remains the same. Another example is given in (2).

(2) 1. Linguistic classification - Witoto - dialect buие

2. Socio-cultural classification - Observed Situations - Profane situations - Social Frame Solidarity Group $-\underline{\text { Minga }}$

3. Socio-cultural classification - Observed Situations - Profane situations - Activities Horticulture-Slashing the underwood.

The situation in (2) is characterized by three terminal node ends of the three branches that define the situation. It consists of a conversation in the Witoto bиие dialect, recorded during a cooperative work in the social frame of a "solidarity group" devoted to cut the forest under-store for a new garden.

\section{CONCLUSION}

We hope to have shown how the principles underlying the hierarchical corpus tree allows us to depart from the mere observation of concrete, perceptible facts. They are meant to help to arrive at categories that structure the social life of the People of the Center (and other peoples) and assign discourse situations (or, more general, socio-cultural situations) to the organization of the social practices. This was discussed above in particular with respect to the subdivision into two big categories: ritual and everyday practice, which are distinguished precisely according to their forms of discourse.

We do not pretend to offer a universal classification of discourse situations with the analytical framework presented here; on the contrary, according to specific properties of societies or communities certain lowlevel branches are obviously not pertinent (e.g. certain kinds of songs), whereas for others more branches will have to be added (for example, in cases where writing traditions are in use). However, we are convinced that the basic distinctions of this analytical approach can be fruitfully applied to other Amerindian societies, and possibly to other tribal societies all over the world.
It seems evident that a classificatory tree of a language documentation project, e.g. a DOBES project, that shares at least some basic properties and distinctions with that of other projects contributes to a much larger transparency of the entire archive than all the diverse and in some cases apparently rather arbitrary classifications adopted until now by the different documentation projects.

Let us conclude by the quotation of an early text of Lévi-Strauss who celebrated his $100^{\text {th }}$ birthday last year. Lévi-Strauss (1967: 68) observed about the relationship between language and culture that "among us, language is used in a rather reckless way we talk all the time, we ask questions about many things. This is not at all a universal situation. There are cultures - and I am inclined to say most of the cultures of the world - which are rather thrifty in relation to language. They don't believe that language should be used indiscriminately, but only in certain specific frames of reference and somewhat sparingly." Our conceptual framework and classificatory tree allows us to precisely assign the sessions in our documentation to socio-cultural situations or, as LéviStrauss puts it, "certain specific frames of reference", which define for what purpose, about what and when the discourse occurs and in which manner or form.

\section{BIBLIOGRAFIA CITADA}

Bajtin M. M. 1995. "El problema de los géneros discursivos". In: Estética de la creación verbal. México: Siglo XXI, 248-293.

Bauman, R. 1977. Verbal art as performance. Prospect Heights Il.: Waveland Inc. Press.

Clastres, P. 1974. La société contre l'état. Paris : Les Éditions de Minuit.

Clastres, P. 1980. Recherches d'anthropologie politique. Paris: Seuil.

Descola, Ph. 1988. "La chefferie amérindienne dans l'anthropologie politique". En: Revue Française de Science Politique 38(5): 818-827.

Gasché, J. 2007. “¿Para qué sirve el concepto de 'sociedad bosquesina'?" In Folia amazónica 16(12): 81-88. Instituto de Investigacioǹ de la Amazonià Peruana.

Gasché, J. To appear a: Pas de rhétorique sans musique: Aspects d'une rhétorique "non classique" en Amazonie. Manuscript accepted for publication.

Gasché, J. To appear b: Witoto rhetoric culture. Manuscript accepted for publication.

Gasché, J.; Echeverri, J. A., 2004. “Hacia una 
sociología de las sociedades bosquesinas". In: Ochoa Jaramillo D.; Guio Rodriguez C.A.: Control social y coordinación: Un camino hacia la sostenibilidad amazónica. Bogotá: Defensoría del Pueblo, Universidad Nacional de Colombia, Corpoamazonía, Parques Nacionales de Colombia. 165-181.

Gasché, J.; Vela Mendoza, N. 2004. Estudios de incentivos para conservación y uso sostenible de la biodiversidad en bosques de comunidades bosquesinas. IIAP, CIES, Iquitos, Manuscript (in press as a first volume of Sociedad Bosquesina).

Gasché, J.; Vela Mendoza, N.; Vela Mendoza, J.C.; Babilonia Cáceres, E., 2005. Libertad, dependencia y constreñimiento en las sociedades bosquesinas amazónicas. ¿Qué significa para los bosquesinos "autonomía”, "ciudadanía” y "democracia? IIAP, CONCYTEC, Iquitos, Manuscript (in press as a second volume of Sociedad Bosquesina).

Gumperz, J. J., Hymes, D. (eds.) 1964: The ethnography of communication. (= Special issue of American Anthropologist 66(6), II).

Gumperz, J. J., Hymes, D. (eds.) 1972. Directions in sociolinguistics: the ethnology of communication. New York: Holt, Rinehart and Winston.

Holzkamp, K. 1985. Grundlegung der Psychologie. Frankfurt/New York: Campus Verlag.

$\mathrm{H}$ o $1 \mathrm{z} \mathrm{k} \mathrm{a} \mathrm{m} \mathrm{p,} \mathrm{K.} 1995$. Lernen. Subjektwissenschaftliche Grundlegung. Frankfurt/New York: Campus Verlag.

Holzkamp, K. 1997-2006. Schriften I, II, III. Berlin: Argument Verlag.

Hymes, D. 1962: "The ethnography of speaking." In: T. Gladwin, W. C. Sturtevant (eds.): Anthropology and human behavior. 13-53. Washington, D.C.: The Anthropological Society of Washington

Hymes, D. 1981. In vain I tried to tell you: Essays in native American ethnopoetics. Philadelphia: University of Pennsylavania Press.

Jacobson, R. 1960: "Closing statements: linguistics and poetics." In: T. A. Sebeok (ed.): Style in language. Cambridge, Mass.: M.I.T. Press. 35073.

Kennedy, G. A. 1998. Comparative Rhetoric. An historical and cross-cultural introduction. New York, Oxford: Oxford University Press.
Leontiev, A. N. 1984. Actividad, conciencia y personalidad. México: Editorial Cartago.

Leontiev, A. 1984. Activité, conscience, personnalité. Moscou:Éditions du Progrès.

Lévi-Strauss, C. 1944. "The social and psychological aspects of chieftainship in a primitive society : The Nambikwara." Transactions of the New York Academy of Sciences 2(7/1).

Lévi-Strauss, C. 1967: Structural Anthropology. New York: Basic Books.

Santos-Granero, F. 1986. "Power, ideology and the ritual of production in Lowland South America". In: Man 21(4): 657-79.

Seifart, F. 2008. "On the representativeness of language documentations". In Language Documentation and Description 5: 60-76.

Seifart, F., Fagua, D., Gasché, J. \& Echeverri, J. A. (eds.). 2009: A multimedia documentation of the languages of the People of the Center. Online publication of transcribed and translated Bora, Ocaina, Nonuya, Resígaro, and Witoto audio and video recordings with linguistic and ethnographic annotations and descriptions. Nijmegen, DOBES-MPI.

Sherzer, J. 1990. Verbal art in San Blas: Kuna culture through its discourse. Cambridge: Cambridge University Press.

Sherzer, J., Urban, G. (eds.) 1986. Native South American discourse. Berlin: Mouton and de Gruyter.

Sherzer, J., Woodbury, A. (eds.) 1987. Native American discourse: poetics and rhetoric. Cambridge: Cambridge University Press.

Todorov, Tz. 1981. Mikhaïl Bakhtine, le principe dialogique, suivi de: Écrits du Cercle de Bakhtine. Paris: Éditions du Seuil.

Urban, G. 1991. A discourse-centered approach to culture: Native South American myths and rituals. Austin: University of Texas Press.

Vološinov V. N. 2010. Marxisme et philosophie du langage. Les problèmes fondamentaux de la méthode sociologique dans la science $d u$ langage. Nouvelle édition bilingue traduite du russe par Patrick Sériot et Inna TylkowskiAgeeva . Limoges, Lambert-Lucas. 


\section{ANNEX}

"Detailed classificatory tree" for archiving socio-cultural and linguistic documents of simple societies, illustrated by the society of the "People of the Center"

\section{LINGUISTIC CLASSIFICATION}

1.1. Bora

1.1.1. Dialect bora

1.1.1.1. Songs

$$
\begin{aligned}
& \text { 1.1.1.1.1. Solo songs } \\
& \text { 1.1.1.1.2. Duo songs } \\
& \text { 1.1.1.1.3. Chorus songs } \\
& \text { 1.1.1.1.1. Other songs }
\end{aligned}
$$

1.1.1.2. Narratives

$$
\text { 1.1.1.1. Icaros }
$$

1.1.1.2.2. Stories

1.1.1.3. Conversation

1.1.1.4. Manguaré

1.1.1.5. Milieu

1.1.2. Dialect miraña

\subsection{Muinane}

1.3. Huitoto

1.2.1. Dialect buue

$$
\text { 1.2.1.1.Songs }
$$

1.2.1.1.1. Solo songs

1.2.1.1.1.1. Fakarilla

1.2.1.1.1.2. Somarafue

1.2.1.1.1.3. Icaros

1.2.1.1.2. Duo songs

1.2.1.1.3. Chorus songs

1.2.1.1.4. Other songs

1.2.1.2. Formal speech

1.2.1.3. Narratives

1.2.1.4. Conversation

1.2.1.5. Manguaré

1.2.1.6. Milieu

1.2.2. Dialect mïka

1.2.3. Dialect mïnïka

1.2.3.1. Songs

1.2.3.1.1. Solo songs

$$
\begin{aligned}
& 1.2 .3 \cdot 1.1 .1 . \text { Fakarilla } \\
& 1.2 .3 \cdot 1.1 .2 . \text { Somarafue } \\
& 1.2 .3 \cdot 1.1 .3 \text {. Icaros }
\end{aligned}
$$

1.2.3.1.2. Duo songs

1.2.3.1.3. Chorus songs

1.2.3.2. Formal speech

1.2.3.1.4. Other songs

1.4. Ocaina

1.2.4. Dialect nïpode

1.2.3.3. Narratives

1.2.3.4. Conversation

1.2.3.5. Manguaré

1.2.3.6. Milieu

1.3.1. Dialect dyuhaya

1.3.2. Dialect uvóhsa 
1.5. Nonuya

1.3.2.2. Formal speech

1.3.2.1.1. Solo songs

1.3.2.1.2. Duo songs

1.3.2.1.3. Chorus songs

1.3.2.1.1. Other songs

1.3.2.3. Narratives

1.3.2.3.1. Icaros

1.3.2.3.2. Stories

1.3.2.4. Conversation

1.3.2.5. Manguaré

1.3.2.6. Milieu

1.6. Resígaro

1.7. Andoque

\section{SOCIO-CULTURAL CLASSIFICATION}

\subsection{Observed situations}

2.1.1. Ritual situations

2.1.1.1. Daily situation (square of the coca)

2.1.1.2. Occasional situations

2.1.1.2.1. Festivals

2.1.1.2.1.1. Festival types

2.1.1.2.1.1. Bora

2.1.1.2.1.1.2. Muinane

2.1.1.2.1.1.3. Huitoto

2.1.1.2.1.1.4. Nonuya

2.1.1.2.1.1.5. Ocaina

2.1.1.2.1.1.6. Resígalo

2.1.1.2.1.1.7. Andoque

2.1.1.2.1.2. Phases (or sequences)

2.1.1.2.1.2.1. Preparación

2.1.1.2.1.2.1. Men's activities

2.1.1.2.1.2.1.1.1. Tobacco

2.1.1.2.1.2.1.2. Coca

2.1.1.2.1.2.1.1.3. Vegetable salt

2.1.1.2.1.2.1.1.4. Fabric. of music instrum.

2.1.1.2.1.2.1.1.5. Fabrication of masks

2.1.1.2.1.2.1.2. Women's activities

2.1.1.2.1.2.1.2.1. Cahuana

2.1.1.2.1.2.1.2.2. Sweet manioc broth

2.1.1.2.1.2.1.2.3. Casabe

2.1.1.2.1.2.1.2.4. Tamales

2.1.1.2.1.2.1.2.5. Painting

2.1.1.2.1.2.1.3. Discourses

2.1.1.2.1.2.1.3.1. Mythical

2.1.1.2.1.2.1.3.2. Performative

2.1.1.2.1.2.1.3.3. Memorized

2.1.1.2.1.2.1.3.4. Informal

2.1.1.2.1.2.1.4. Cantos

2.1.1.2.1.2.1.4.1. Drinking songs (duos)

2.1.1.2.1.2.2. Celebration of the festival

2.1.1.2.1.2.2.1. Delivery of the gifts (game, fish, fruits)

2.1.1.2.1.2.2.2. Reception of the guests 
2.1.1.2.1.2.2.3. Payment of the gifts

2.1.1.2.1.2.2. Ritual services (masks, flutes....)

2.1.1.2.1.2.2.5. Farewell

2.1.1.2.1.2.2.6. Conversations

2.1.1.2.1.2.7. Discourses

2.1.1.2.1.2. 2.8 . Songs

2.1.1.2.1.2.2.8.1. Flute songs

2.1.1.2.1.2.2.8.2. Men's songs (solos)

2.1.1.2.1.2.2.8.3. Chorus songs

2.1.1.2.1.2.2. 2.3 .1 . Songs for entry

2.1.1.2.1.2.2.8.3.2. Songs for day

2.1.1.2.1.2.2.8.3.3. Songs for night

2.1.1.2.1.2.2.8.3.4. Song for dawn

2.1.1.2.2. Healing

2.1.1.2.1.2.2.8.3.5. Songs f. parting

2.1.1.2.2.1. Prayers

2.1.1.2.2.2. Preventive y propitiatory formulae

2.1.1.2.3. Inter-communal (« inter-maloca ») drum communication (manguaré)

\subsubsection{Everyday (profane) situations}

2.1.2.1. Social framework

2.1.2.1.1. Domestic unity

2.1.2.1.1.1. In the house

2.1.2.1.1.2. In the garden and abandoned plots

2.1.2.1.1.3. During bath

2.1.2.1.1.4. In the forest

2.1.2.1.1.5. In the river

2.1.2.1.2. Solidarity groups

2.1.2.1.2. Minga

2.1.2.1.2.2. Help

2.1.2.1.2.3. Food sharing

2.1.2.1.3. Community

2.1.2.1.3.1. Assembly

2.1.2.1.3.2. Comunal work

2.1.2.1.4. Institutions

2.1.2.1.4.1. School (teachers, pupils)

2.1.2.1.4.2. Association of schoolchildren's parents

2.1.2.1.4.3. Sport club

2.1.2.1.4.4. Church

2.1.2.1.4.5. Foklore group

2.1.2.1.4.6. Indigenous federation

2.1.2.1.4.6.1. Congress

2.1.2.1.4.6. Leader's session

2.1.2.1.5. City

2.1.2.2. Activities

2.1.2.2.1. Rest

2.1.2.2.1.1. Narration

2.1.2.2.1.1.1. Myths

2.1.2.1.1.2. Life stories

2.1.2.2.1.1.3. Historical narratives

2.1.2.2.1.1.4. Hunting stories

2.1.2.2.1.2. Songs

2.1.2.2.1.3. Conversation

2.1.2.2.2. Gathering

2.1.2.2.2.1. Savage fruits 
2.1.2.2.2. Tamshi (lianas)

2.1.2.2.2.3. Chambira (palm fibers)

2.1.2.2.2.4. Vegetable and mineral dyes

2.1.2.2.2.5. Other vegetable products

2.1.2.2.2.6. Toads, frogs, shrimps, crayfishes, tortoises

2.1.2.2.2.7. Insects and larvae

2.1.2.2.3. Logging (timber exploitation)

2.1.2.2.4. Hunting

2.1.2.2.5. Fishing

2.1.2.2.6. Horticulture

2.1.2.2.6.1. Slashing the underwood

2.1.2.2.6.2. Felling the trees

2.1.2.2.6.3. Burning

2.1.2.2.6.4. Shunteo (burning chipped, amassed branches)

2.1.2.2.6.5. Sowing

2.1.2.2.6.5.1. Tobacco

2.1.2.2.6.5.2. Coca

2.1.2.2.6.5.3. Manioc

2.1.2.2.6.5.4. Otros tubers

2.1.2.2.6.5.5. Plantains

2.1.2.2.6.5.6. Corn

2.1.2.2.6.5.7. Peanut

2.1.2.2.6.5.8. Pine-apple

2.1.2.2.6.5.9. Fruit trees

2.1.2.2.6.5.10. Other cultigens

2.1.2.2.6. 6. Harvesting

2.1.2.2.6.6.1. Tobacco

2.1.2.2.6.6.2. Coca

2.1.2.2.6.6.3. Manioc

2.1.2.2.6.6.4. Other tubers

2.1.2.2.6.6.5. Plantain

2.1.2.2.6.6.6. Corn

2.1.2.2.6.6.7. Peanut

2.1.2.2.6.6.8. Pine-apple

2.1.2.2.6.6.9. Cultivated fruits

2.1.2.2.6.6.10. Other cultigens

2.1.2.2.7. Building

2.1.2.2.8. Handicaft

2.1.2.2.8.1. Pottery

2.1.2.2. 2 . Chambira (work with palm fibres)

2.1.2.2.8.3. Llanchama (work with bark liber)

2.1.2.2.8.4. Balsa (work with balsa wood)

2.1.2.2.8.5. Gourd

2.1.2.2.8.6. Seeds

2.1.2.2.8. Dyes and paintings

2.1.2.2.9. Kitchen and domestic activities

2.1.2.2.9.1. Food preparation

2.1.2.2.9.1.1. Manioc

2.1.2.2.9.1.2. Pepper

2.1.2.2.9.1.3. Plantain

2.1.2.2.9.1.4. Corn

2.1.2.2.9.1.5. Macambo (Theobroma bicolor)

2.1.2.2.9.1.6. Umarí (Poraqueiba sericea)

2.1.2.2.9.1.7. Sacha-inchi (Plukenetia plyadenia)

2.1.2.2.9.1.8. Other products

2.1.2.2.9.1.9. Fish 
2.1.2.2.9.1.10. Meat

2.1.2.2.9.1.11. Insects, larvae

2.1.2.2.9.2. Consumption of food

2.1.2.2.9.3. Domestic cleaning

2.1.2.2.10. Commerce

2.1.2.2.10.1. Selling in front of the house

2.1.2.2.10.2. Selling from house to house

2.1.2.2.10.3. Shop selling

2.1.2.2.10.4. Ambulatory trader

2.1.2.2.10.5. Communal market (handicraft, food)

2.1.2.2.10.6. Urban market

2.1.2.2.11. Turisme, folclore

2.1.2.2.11.1. Assembly of folclore group

2.1.2.2.11.2. Training

2.1.2.2.11.3. Reception

2.1.2.2.11.4. Guide's explications

2.1.2.2.11.5. Representations

2.1.2.2.11.6. Selling of handicraft

2.1.2.2.11.7. Visit into the community

2.1.2.2.12. Clothes washing

2.1.2.2.13. Body care and hygienics

2.1.2.2.14. Extradomestic cleaning (around the house, on the street... )

2.1.2.2.15. Children rearing and nursing

2.1.2.2.16. Children's and youth's games

2.1.2.3.17. Sport

2.1.2.3.18. Intra- and inter-communal drum communication

\subsection{Situations created by the linguist or anthropologist}

2.2.1. Lexical inquiries

2.2.2. Morpho-syntactic elicitation

2.2.3. Inter-communal (recorded) communications

2.2.4. Inquieries about society and culture

2.2.4.1. Drum language (manguaré)

2.2.4.2. Festivals

2.2.4.2.1. Narratives/myths about the origin

2.2.4.2.2. Ritual discourses

2.2.4.2.3. Songs

2.2.4.2.4. Preparation and development of the festival

2.2.4.2.5. Material paraphernalia and adorning

2.2.4.3. Oral litterature (myths, stories, proverbs...)

2.2.4.4. Prayers

2.2.4.5. Life stories

2.2.4.6. Historical narratives

2.2.4.7. Hunting stories

2.2.4.8. Techniques

2.2.4.8.1. Acquisitive techniques

2.2.4.8.1.1. Gathering 2.2.4.8.1.2. Hunting

2.2.4.8.1.3. Fishing

2.2.4.8.2. Transformative techniques

2.2.4.8.2.1. Horticulture

2.2.4.8.2.2. Kitchen

2.2.4.8.2.3. Handicraft

2.2.4.8.2.4. Building

2.2.4.8.3. Consumptive techniques

2.2.4.8.3.1. Use de artefacts 
FO LIA

PROPOSAL FOR A SHARED CLASSIFICATORY TREE FOR DOBES LANGUAGE

Amazónica 1 DOCUM ENTATIONS AND OTHER SOCIO-CULTURAL DATA BASES.

2.2.4.8.3.2. Commerce

2.2.4.8.3.3. Consumption of food

2.2.4.9. Ethno-medicine

2.2.4.10. Ethno-botany

2.2.4.11. Ethno-zoology

2.2.4.12. Ethno-ecology

\subsection{Habitat, geophysical and ecological milieu}

